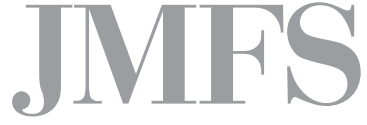

Journal of Management and Financial Sciences
Volume XII

Issue 38 (September 2019)

pp. $47-60$

Warsaw School of Economics

Collegium of Management and Finance

Andor Máté

Faculty of Economics and Business Administration

University of Szeged

\title{
Interactions between the budget and the current account balance: twin deficits in selected Central and East European countries
}

\begin{abstract}
Nowadays, especially after the global financial crisis of 2008, the external and internal balance of individual countries has become a major area of research. This is even more important in the CEE region, as the crisis has shown that imbalances in this region have significantly increased their sensitivity to the crisis. In our research, we aim to explore whether there is, if any, relationship between fiscal policy and the balance of the current account in Poland, Hungary and the Czech Republic. The period which we will analyse is the last two decades since the millennium. Based on a literature review, we examine the relationship between the budget deficit and the current account with econometric methods, Engle-Granger cointegration test and Vector Error Correction Model (VECM). Our results will show that we can find different, if any, relationship between the two factors in the different countries. It means, however, that there are a lot of similarities between these countries, from this point of view they are quite heterogeneous. Thus, in this field, there is not one general solution for every country; each country has to find their way to handle the twin deficit problem.
\end{abstract}

Keywords: twin deficit, budget balance, current account balance JEL Classification Codes: F32, H62 


\section{Introduction}

In the last decades, several studies have been conducted about the relationship between the current account and the budget balance, with other worlds between the external balance and the fiscal policy. These examinations came to the front after the oil crises, at the end of the 1970s and the first years of the 1980s, firstly in the United States and later in other countries. Nowadays, especially after the global financial crisis of 2008, the external and internal balance of individual countries has become a major area of research. In the last ten years, there have been several economies worldwide, including in Europe, which have had to confront their internal and external imbalances. This is true for Central and East European countries, too, and in this study, we analyse three of them: Poland, Hungary and the Czech Republic.

Our paper will have three main parts and a conclusion at the end of the study. Firstly, we will present a brief literature review to become familiar with the theoretical background of the twin deficit and with the previous results. After that, we introduce our methodology which we use in this analysis, and in the last main part, we will present our empirical results. Finally, we will summarise the results and discuss the major conclusions.

\section{Literature review}

In this chapter we would like to introduce the reader to the related twin deficit theories and to previous studies on our topic: which countries have been examined, what econometric models were used and what empirical results were determined. The methodology of the subject literature is extremely diverse, ranging from the simple regression calculation, vector autoregression models, and Granger-causality testing to the cointegration models; their order as listed below, being broadly chronologic.

\subsection{Theoretical background}

To begin with, let us start with the basic macroeconomic context, which says that:

$$
\mathrm{Y}=\mathrm{C}+\mathrm{I}+\mathrm{G}+\mathrm{NX}+\mathrm{R}
$$

where $\mathrm{Y}$ is the domestic product, $\mathrm{C}$ is the consumption of the private sector, $\mathrm{I}$ is investment, $\mathrm{G}$ is government spending, NX is the net export (Export - Import) and $\mathrm{R}$ is the value of the transfers. One can transform this equation to:

$$
\mathrm{Y}-\mathrm{T}-\mathrm{C}-\mathrm{I}+\mathrm{T}-\mathrm{G}=\mathrm{CA},
$$


where $\mathrm{T}$ is the revenue of the government (taxes), CA is the current account balance, which is equal to $\mathrm{NX}+\mathrm{R}$. After a further transformation, we get:

$$
(\mathrm{S}-\mathrm{I})+(\mathrm{T}-\mathrm{G})=\mathrm{CA},
$$

where $\mathrm{S}=\mathrm{Y}-\mathrm{T}-\mathrm{C}$, the savings of the private sector. From this equation we can see that the difference of the private sector's savings and investments and the net savings of the governmental sector give us the balance of the current account. We could see that a change in the budget balance influences the current account in almost every case. The only exception to this is when the Ricardian equivalence is present, which means that because of the increase in the budget deficit, people expect higher taxes in the future, so instead of higher consumption they just increase their savings. In this case, change in the budget deficit has no effect at all on the current account [Barro, 1989]. Actually, there is a perfect negative relationship (-1) between the budget balance (T-G) and the private sector's savings (S).

If the above-mentioned theoretic concept is not present, there is a relationship between the budget and current account balance. We come across several discussions in the scientific literature about this relationship, invariably on the question of which balance is the cause, and which the effect. The common attitude is the budget balance is seen as the cause, and the external balance as the effect [Darrat, 1988; Abell, 1990; Salvatore, 2006]. The presence of this relationship, actually, is based on the Keynesian macroeconomy and is first described in the Mundell-Fleming model [Mundell, 1963; Fleming, 1962]. It claims that an increasing budget deficit causes increasing domestic real interest rates, which generate capital inflow and a stronger domestic currency, and finally, this stronger currency induces the deteriorating current account balance. However, several studies [Summers, 1986; Kim, Roubini, 2008] say that we cannot consider the budget balance as an exogenous variable, because many governmental measures are taken as a response to the undesirable current account balance.

The reverse link is based on the so-called neoclassical concept [Magazzino, 2012] and many empirical studies have shown this relationship. This relationship is traditionally perceptible in the case of states which are small, open and largely acting with foreign capital inflows [Baharumsah et al., 2006], so this phenomenon cannot be excluded in our examined countries. The main point of this causal relationship is that the chronic current account deficit induces a slow, moderate growth, as shown in equation (1), and the government is trying to increase this slow growth with its expansive fiscal policy. As we can see in equation (1), this expansion can be oriented to higher government spending or higher private sector consumption with the help of reduced taxes, aid to private sector and so on. However, the theory may exist in the case of a stable positive current account balance, in which case the government is less in need of this fiscal stimulus.

All in all, the following four theories can be distinguished according to the literature and Kim and Kim [2006]: 
(A) The Ricardian equivalence theory which means that there is no causal relationship between the two balances;

(B) The Keynesian idea meaning that the budget balance has a causal effect on the current account balance;

(C) The theory based on the neoclassical concept which means that the current account balance has an impact on the budget deficit;

(D) Finally, the theory claiming that both of the two balances have a causal effect on the other.

\subsection{Previous empirical results}

The literature of the past decades has empirically proved all four theories, depending on which countries they analysed and the examined time period.

The Keynesian idea was supported by, among others, Bernheim [1988], who examined the twin deficit of the United States and five large trading partners (Canada, the UK, Mexico, West Germany and Japan) in his study between 1960 and 1984, in which he used the traditional regression model and found that the Keynesian twin-deficit theory prevailed in these countries (except Japan). On the basis of the Keynesian concept, fiscal expansion resulted in higher interest rates, which increased the inflow of foreign capital, which further strengthened the currency, thereby worsening the external balance. This idea was also confirmed in the study by Leachman and Francis [2002], who analysed the data of the United States between World War II and the end of the Bretton Woods system, and after the Bretton Woods system. In their research, cointegration and multi-cointegration methods have shown that before 1974 there was only a short-term relationship between the two deficits, and after 1974 they had a longterm but weak relationship. The Keynesian theory was also empirically verified on Greek data in publications of Vamvoukas [1999] and Trachanas and Katrakilidis [2012] (in the latter study the theory was also confirmed on the data of Ireland, Portugal and Spain). In these two papers, the authors also used the cointegration and vector error correction model. Furthermore, the same relationship was shown by the same method in the Akbostanci and Tunc [2002], a paper on Turkish data and in Ratha's study [2012] on Indian data.

Several empirical studies found that there is not any correspondence between the two examined variables, so they indirectly proved the Ricardian equivalence theory. For example, the Ricardian equivalence theory was confirmed by Sen and Kaya [2016] on the example of Czech and Ukrainian data or by Khalid and Guan [1999] on the data of Australia and the United Kingdom.

There are a lot of studies in which the neoclassical view - the external balance's effect on the internal balance - was confirmed. For example, Magazzino [2012] confirmed this view with the vector autoregressive model in the case of Italy, and the above-mentioned Khalid and Guan [1999] study showed a similar relationship on the example of Indonesia and Pakistan. Furthermore, this assumption was confirmed by Marashdeh and Saleh [2006] on Lebanese data with the help of the ARDL model. 
A two-way link has also been confirmed by several empirical studies. Firstly, Abell [1990] showed the assumed Granger-causal relationship between the budget balance and the real interest rate, then between the real interest rate and the exchange rate, then between the exchange rate and the external equilibrium; however, it also showed a significant relationship in the opposite direction, so there was a causal effect of the current account balance on the budget deficit. There is also evidence of a two-way link in Islam's [1998] study with Brazilian data, and in the example of Mukhtar et al. study [2007] on the data of Pakistan.

In the table below (Table 1) we summarise the results of the mentioned empirical studies. Although our literature review is not complete, it can be seen that most of the studies supported the Keynesian idea. This is probably also due to the fact that the Keynesian causal relationship theory is the most widespread, and most of the studies start by assuming that and they try to justify this.

Table 1. Previous empirical results

\begin{tabular}{|c|c|c|}
\hline Authors & Object of analysis & Methods \\
\hline \multicolumn{3}{|c|}{ Studies verifying the Keynesian view } \\
\hline Bernheim [1988] & USA, UK, Canada, Mexico, West Germany & OLS \\
\hline Leachman, Francis [2002] & USA & Cointegration, Multicointegration \\
\hline Vamvoukas [1999] & Greece & Cointegration, VECM \\
\hline Trachanas, Katrakilidis [2012] & Greece, Ireland, Portugal, Spain & Cointegration, VECM \\
\hline Akbostanci, Tunc [2002] & Turkey & Cointegration, VECM \\
\hline Ratha [2012] & India & Cointegration, VECM \\
\hline \multicolumn{3}{|c|}{ Studies verifying the Ricardian approach } \\
\hline Sen, Kaya [2016] & Czech Republic, Ukraine & Granger-causality \\
\hline Khalid, Guan [1999] & Australia, UK & Granger-causality \\
\hline \multicolumn{3}{|c|}{ Studies verifying the neoclassical view } \\
\hline Magazzino [2012] & Italy & VAR \\
\hline Khalid, Guan [1999] & Indonesia, Pakistan & Granger causality \\
\hline Marashdeh, Saleh [2006] & Lebanon & ARDL \\
\hline \multicolumn{3}{|c|}{ Studies verifying the two-way causal relationship } \\
\hline Abell [1990] & USA & Granger causality \\
\hline Islam [1998] & Brazil & Granger causality \\
\hline Mukhtar et al. [2007] & Pakistan & Cointegration, Granger causality \\
\hline
\end{tabular}

Source: own elaboration.

\section{Methodology}

In the following part of the study we describe the methodology of our analysis and its background, present the preconditions of the used methodological tools, and then outline how to find long- and short-term causal relationships between our two-time series. 
As we have seen in the literature review above, most of the literature has been looking for the Granger causality between the two variables or analysed cointegration between the current account balance and the budget balance, and we would also like to use this method. The advantage of studying cointegration is that with our resulting vector error correction model, we can detect long-term and also short-term causal relationships between our variables. If it turns out that our two-time series are not cointegrated, then we can work with a simple vector autoregressive model, thus showing a short-term relationship between our variables. I will use the other mentioned device, the Granger causality, to check whether the two-time series are really cointegrated because if they are cointegrated, at least one of our variables necessarily Granger causes our other variable [Kirchgassner et al., 2013].

For our time series to be cointegrated, it is first necessary that the two (or more) time series should be integrated in the same order. This usually means that these processes can be considered as unit roots, I (1) processes (but theoretically it cannot be excluded that each time series is I (2) process) and their difference is already stationary (I (0)), ${ }^{1}$ Stationarity means that the expected value and standard deviation of the differentiated time series can be considered constant in time. Then we estimate the so-called cointegrating equation (4) and we analyse its error term:

$$
X_{t}=a_{0}+a_{1} Y_{t}+E_{t}
$$

where $E_{t}$ is the error term of the equation. If this error term time series is stationary and not a unit root process, then the two (or more) time series are cointegrated [Engle and Granger, 1987]. If this cointegration stands, then we can write the following error correction representation between two variables:

$$
\begin{gathered}
\Delta X_{t}=\alpha_{0}+\alpha_{1} E_{t-1}+u_{t}, \\
\Delta Y_{t}=\beta_{0}+\beta_{1} F_{t-1}+v_{t},
\end{gathered}
$$

where $\Delta X_{t}$ is the change of the $X$ variable in the period $t$, and $E_{t-1}$ is the error-correction term, the lagged value of the residual from the cointegrating regression (4) and $\alpha_{1}$ shows how many percent of the lagged residual is corrected in the period $t$, and $u_{t}$ is the error term [Engle and Granger, 1987]. The same interpretations are true for $\Delta Y_{t}, v_{t}, F_{t-1}$ and $\beta_{1}$. After estimating these equations, we can conclude from the significant or insignificant $\alpha_{1}$ and $\beta_{1}$ parameters which variable adapts to our other variable in the long run, so we can find the direction of causal relationship between our variables.

1 Here we mean the weak stationary, that is, the constant expected value in time and covariance stationarity, we do not assume a constant distribution in time. 
The advantage of this model is that it can be easily completed by considering short-term effects. In the first step, we can see that $X_{t}$ and $Y_{t}$ are unit root processes, so $\Delta X_{t}$ and $\Delta Y_{t}$ are stationary. Furthermore, in the case of cointegration, error correction terms $\left(E_{t-1}\right.$ and $\left.F_{t-1}\right)$ are also stationary. It means there are just stationary variables on both side of the equation (5) and (6), so we can complete the equations with further stationary variables, which, in our case, are the lagged values of differentiated time series [Lütkepohl, 2005]. So we can get the following representations:

$$
\begin{gathered}
\Delta X_{t}=\alpha_{0}+\alpha_{1} E_{t-1}+\sum_{i=1}^{n} \alpha_{2 i}(1-L) \Delta X_{t-i}+\sum_{i=1}^{n} \alpha_{3 i}(1-L) \Delta Y_{t-i}+u_{t}, \\
\Delta Y_{t}=\beta_{0}+\beta_{1} F_{t-1}+\sum_{i=1}^{n} \beta_{2 i}(1-L) \Delta X_{t-i}+\sum_{i=1}^{n} \beta_{3 i}(1-L) \Delta Y_{t-i}+v_{t},
\end{gathered}
$$

where $L$ is the lag operator, $\Delta X_{t-i}$ and $\Delta Y_{t-i}$ are the change of the $\mathrm{X}$ and $\mathrm{Y}$ variable in the previous period. By using the changes of the previous periods in our model, we have already get a model which we can use to analyse the short-term causal effect in addition to the longterm relationship. If $\alpha_{2 i}, a_{3 i}, \beta_{2 i}$ or $\beta_{3 i}$ coefficients are significant, we can find a short-term causal relationship between the variables. All in all, we can see it is, actually, a simple vector autoregressive model extended with the error correction terms.

\section{Empirical analysis and results}

In the following part, we present the data we used, the used methodological tools described above, and what our results are which we obtained with our analysis.

In our examination, we examined the effect of the two balances on each other and whether they are cointegrated. In order to do this, we used seasonally and calendary adjusted quarterly data of the current account balance to GDP and budget deficit to GDP ratio from the database of Eurostat. Due to the elimination of the crisis effect, we extend the equations with a crisis dummy as an exogenous variable, we designed the crisis period relying on the CEPR (Center for Economic Policy Research) database, where they identify the periods of recession.

In the first step, we examined whether the two-time series are unit processes. We can use for this step the so-called Augmented Dicky-Fuller test [Kiss, 2017]. The results of this test can be seen in the following table (Table 2). Based on this table, in the case of non-differentiated data, we cannot reject the null hypotheses, which say the time series are unit root processes. However, in the case of differentiated data, we can reject the null hypotheses, so the differentiated time series are stationary. Our time series are I (1) processes, so we can continue with the estimation of the cointegrating equations.

Accordingly to the mentioned Engle-Granger test, we examined whether the error term of the cointegrating equations are stationary or not. Based on the p-values of the Engle-Granger tests (Table 3), the error term is stationary in the case of Hungary and the Czech Republic, 
and it is a unit root process in the case of Poland. It means the two-time series is cointegrated in the Czech and Hungarian case, and they are not cointegrated in the Polish case. In view of these results, there is not long-term relationship between the external and internal balance in Poland. The reason for this phenomenon could be the large dimension of the Polish economy: the economy is quite large, so the current account and budget balance could be determined individually. In the following part, we will discuss the two cases in which the long-term relationship stands.

Table 2. Results of Augmented Dicky-Fuller tests

\begin{tabular}{|l|c|c|c|c|c|c|}
\cline { 2 - 7 } \multicolumn{1}{c|}{} & \multicolumn{2}{c|}{ Poland } & \multicolumn{2}{c|}{ Hungary } & \multicolumn{2}{c|}{ Czech Republic } \\
\hline \multicolumn{1}{c|}{ Time series } & t-ratio & $p$-value & t-ratio & $p$-value & t-ratio & $p$-value \\
\hline $\mathrm{CA} / \mathrm{GDP}$ & -2.748345 & 0.0722 & -0.949681 & 0.7669 & -1.197371 & 0.6718 \\
\hline$\Delta(\mathrm{CA} / \mathrm{GDP})$ & -6.676088 & 0.0000 & -9.642129 & 0.0000 & -20.46306 & 0.0001 \\
\hline $\mathrm{BD} / \mathrm{GDP}$ & -1.824981 & 0.3650 & -1.479874 & 0.5384 & -2.455177 & 0.1305 \\
\hline$\Delta(\mathrm{BD} / \mathrm{GDP})$ & -9.397273 & 0.0000 & -9.458691 & 0.0000 & -7.298294 & 0.0000 \\
\hline
\end{tabular}

Source: own estimation.

Table 3. Results of Engle-Granger tests

\begin{tabular}{|l|c|c|}
\hline \multicolumn{1}{|c|}{ Time series } & t-ratio & p-value \\
\hline Error term in the case of Poland & -2.41172 & 0.3302 \\
\hline Error term in the case of Hungary & -6.66023 & 0.0000 \\
\hline Error term in the case of Czech Republic & -5.00129 & 0.0005 \\
\hline
\end{tabular}

Source: own estimation.

As we could see, if two time series are cointegrated, at least one of them necessarily Granger causes the other. Table 4 shows that, in the case of Hungary and the Czech Republic, this assumption stands indeed, because we can reject the null hypothesis in the second and third row.

Table 4. Results of Granger causality tests

\begin{tabular}{|l|c|c|}
\hline \multicolumn{1}{|c|}{ Null hypothesis } & F-statistic & p-value \\
\hline BD does not Granger cause CA in the case of Hungary & 0.27622 & 0.7595 \\
\hline CA does not Granger cause BD in the case of Hungary & 3.32839 & 0.0415 \\
\hline BD does not Granger cause CA in the case of the Czech Republic & 8.12921 & 0.0007 \\
\hline CA does not Granger cause BD in the case of the Czech Republic & 0.81911 & 0.4449 \\
\hline
\end{tabular}

Source: own estimation.

With the proven cointegrated time series we can continue our examination with the Vector Error Correction Models (VECM). We estimated the above written equation (7) and (8) with the error-correction terms, the lagged values of the endogenous variables and the 
mentioned crisis dummy. The $X_{t}$ and $Y_{t}$ variables were the GDP-related current account balance and the GDP-related governmental deficit. The results of the VECM-estimations can be seen below (Table 5, 6 and Appendix 1,2) In order to interpret these equations, the absence of autocorrelation is also necessary. The first-order autocorrelation is not present based on the Durbin-Watson values ( 2), but more generally, we also could not find a significant autocorrelation with 20 period lag.

Table 5. VECM estimation on the budget deficit in Hungary

\begin{tabular}{|c|c|c|c|c|}
\hline & \multicolumn{4}{|c|}{$\Delta(\mathrm{BD} / \mathrm{GDP})_{\mathrm{t}}$} \\
\hline & Coefficient & Std. error & t-ratio & $\mathrm{p}$-value \\
\hline const. & -1.62002 & 0.72188 & -2.244 & $0.0281^{* \star}$ \\
\hline$\Delta(\mathrm{BD} / \mathrm{GDP})_{\mathrm{t}-1}$ & -0.29116 & 0.15906 & -1.830 & 0.0716 \\
\hline$\Delta(\mathrm{BD} / \mathrm{GDP})_{\mathrm{t}-2}$ & -0.15058 & 0.12634 & -1.192 & 0.2375 \\
\hline$\Delta(\mathrm{CA} / \mathrm{GDP})_{\mathrm{t}-1}$ & -0.21353 & 0.13710 & -1.557 & 0.1240 \\
\hline$\Delta(\mathrm{CA} / \mathrm{GDP})_{\mathrm{t}-2}$ & -0.19721 & 0.13515 & -1.459 & 0.1491 \\
\hline Crisis & 0.371304 & 0.83724 & 0.4435 & 0.7046 \\
\hline Error-correction term & -0.18239 & 0.06530 & 2.793 & $0.0068^{* * *}$ \\
\hline Mean dependent var & 0.072000 & \multicolumn{2}{|c|}{ S.D. dependent var } & 3.352956 \\
\hline Sum squared resid & 503.3970 & \multicolumn{2}{|c|}{ S.E. of regression } & 2.720827 \\
\hline R-squared & 0.394905 & \multicolumn{2}{|c|}{ Adjusted R-squared } & 0.341515 \\
\hline rho & -0.067065 & \multicolumn{2}{|c|}{ Durbin-Watson } & 2.063344 \\
\hline
\end{tabular}

Source: own estimation.

Table 6. VECM estimation on the current account balance in the Czech Republic

\begin{tabular}{|l|c|c|c|c|}
\cline { 2 - 4 } \multicolumn{1}{c|}{} & \multicolumn{3}{c|}{$\Delta(\mathrm{CA} / \mathrm{GDP})_{\mathrm{t}}$} \\
\cline { 2 - 5 } \multicolumn{1}{c|}{} & Coefficient & Std. error & t-ratio & p-value \\
\hline const. & 0.056514 & 0.47300 & 0.1195 & 0.9052 \\
\hline$\Delta(\mathrm{BD} / \mathrm{GDP})_{\mathrm{t}-1}$ & -0.54644 & 0.25035 & -2.183 & $0.0325^{* *}$ \\
\hline$\Delta(\mathrm{BD} / \mathrm{GDP})_{\mathrm{t}-2}$ & -0.38735 & 0.21888 & -1.770 & 0.0813 \\
\hline$\Delta(\mathrm{CA} / \mathrm{GDP})_{\mathrm{t}-1}$ & 0.318819 & 0.16924 & 1.884 & 0.0639 \\
\hline$\Delta(\mathrm{CA} / \mathrm{GDP})_{\mathrm{t}-2}$ & -0.00012 & 0.12099 & -0.001 & 0.9992 \\
\hline Crisis & 0.188948 & 1.16564 & 0.1621 & 0.8717 \\
\hline Error-correction term & -1.02790 & 0.177965 & 5.776 & $0.0000^{* * *}$ \\
\hline Mean dependent var & 0.020000 & S.D. dependent var & 5.316395 \\
\hline Sum squared resid & 923.6315 & \multicolumn{2}{c|}{ S.E. of regression } & 3.685487 \\
\hline R-squared & 0.558396 & Adjusted R-squared & 0.519431 \\
\hline rho & -0.041789 & \multicolumn{2}{c|}{ Durbin-Watson } & 2.078253 \\
\hline
\end{tabular}

Source: own estimation.

Our results show that in Hungary the external balance has an effect on the budget deficit in the long-run and the budget deficit has no effect on the current account. It means that 
in the case of Hungary, the change of the current account balance could be the reason for the improvement or deterioration of the budget balance.

Meanwhile in the Czech Republic, the opposite causal relationship is perceptible than in the Hungarian case, the budget deficit can have a causal effect on the current account. Based on these results, the goverments of these countries should have a different primary goal to achieve the internal and external equilibrum at the same time.

\section{Summary}

At the end of our study, we can state that there are a lot of similarities between the examined countries, from the point of view of the twin deficit they are quite heterogeneous. While in Poland the Ricardian equivalence is noticeable in the long-term (and also short-term, see the Appendix), in Hungary and the Czech Republic we found the neoclassical and Keynesian approach.

It means that in Hungary the change of the current account balance can be the reason for the improvement or deterioration of the budget balance; while in the Czech Republic we can see the opposite relationship. So, in this field, there is not one general solution for every country to achieve the external and internal equilibrum, each country has to find their way to handle the twin deficit problem. Where the neoclassical view stands, the goverment should improve the external imbalance first, and, based on this analysis, the improving current account results in improving internal equilibrium. In the Keynesian case, the consolidation of the budget deficit should be the primary goal. Where the Ricardian approach stands, the government has to consolidate the two balances at the same time.

The main conclusions to be drawn from these results might be that it is worth dealing with external and internal imbalances, as it is a significant problem in the CEE countries, and it can be a relevant implication in practice as well. It is also important to reach the 'twin equlibrium' if this region would like to be a stable and relevant actor of the European Union. In future research, we should expand our knowledge in the field of the countries' economic environment and find the reason why these different twin deficit hypotheses are present in the different countries.

\section{References}

1. Abell, J.D. (1990). Twin deficits during the $1980 \mathrm{~s}$ : an empirical investigation. Journal of Macroeconomics, No. 12(1), pp. 81-96. Retrieved from: https://doi.org/10.1016/0164-0704(90) 90057-H

2. Akbostanci, E., Tunc, G.I. (2002). Turkish twin deficits: An error correction model of trade balance. ERC Working Papers in Economics, No. 01/06. 
3. Baharumshah, A.Z., Lau, E., Khalid, A.M. (2006). T.esting Twin Deficits Hypothesis Using VARs and Variance Decomposition. Journal of the Asia Pacific Economy, No. 11(3), pp. 331-654. Retrieved from: https://doi.org/10.1080/13547860600764245

4. Barro, R.J. (1989). The Ricardian approach to budget deficits. The Journal of Economic Perspectives, No. 3(2), pp. 37-54. Retrieved from: https://doi.org/10.1257/jep.3.2.37

5. Bernheim, B.D. (1988). Budget deficits and the balance of trade. Tax Policy and the Economy, No. 2, pp. 1-31. Retrieved from: https://doi.org/10.1086/tpe.2.20061771

6. Darrat, A.F. (1988). Have large budget deficits caused rising trade deficits? Southern Economic Journal, No. 54(4), pp. 879-887. Retrieved from: https://doi.org/10.2307/1059523

7. Engle, R.E., Granger, C.W.J. (1987). Co-integration and error correction: Representation, estimation and testing. Econometrica, No. 55(2), pp. 251-276. Retrieved from: https://doi. org/10.2307/1913236

8. Fleming, J.M. (1962). Domestic financial policies under fixed and floating exchange rates. IMF Staff Papers, No. 9, pp. 369-379.

9. Islam, M.F. (1998). Brazil's Twin Deficits: An Empirical Examination. Atlantic Economic Journal, No. 26(2), pp. 121-128. Retrieved from: https://doi.org/10.1007/bf02299354

10. Khalid, A.M., Guan, T.W. (1999). Causality tests of budget and current account deficits: Crosscountry comparisons. Empirical Economics, No. 24(3), pp. 389-402. Retrieved from: https:// doi.org/10.1007/s001810050062

11. Kim, C.H., Kim, D. (2006). Does Korea have twin deficits? Applied Economics Letters, No. 13(10), pp. 675-680. Retrieved from: https://doi.org/10.1080/13504850500404910

12. Kim, S., Roubini, N. (2008). Twin deficit or twin divergence? Fiscal policy, current account, and real exchange rate in the U.S. Journal of International Economics, No. 74(2), pp. 362-383. Retrieved from: https://doi.org/10.1016/j.jinteco.2007.05.012

13. Kirchgässner, G., Wolters, J., Hassler, U. (2013). Introduction to Modern Time Series Analyses. Berlin: Springer. Retrieved from: https://doi.org/10.1007/978-3-642-33436-8

14. Kiss, G.D. (2017). Volatilitás, extrém elmozdulások és tőkepiaci fertözések. Szeged: JATEPress Kiadó.

15. Lütkepohl, H. (2005). New Introduction to Multiple Time Series Analysis. Berlin: Springer. Retrieved from: https://doi.org/10.1007/3-540-27752-8

16. Leachman, L.L., Francis, B. (2002). Twin deficits: apparition or reality? Applied Economics Letters, No. 34(9), pp. 1121-1132. Retrieved from: https://doi.org/10.1080/00036840110069976

17. Magazzino, C. (2012) The twin deficits phenomenon: evidence from Italy. Journal of Economic Cooperation and Development, No. 33(3), pp. 65-80.

18. Marashdeh, H., Saleh, A.S. (2006). Revisiting Budget and Trade Deficits in Lebanon: A Critique. University of Wollongong, Faculty of Commerce - Economics Working Papers, 06-07.

19. Mukhtar, T., Zakaria, M., Ahmed, M. (2007). An Empirical Investigation for the Twin Deficit Hypothesis in Pakistan. Journal of Economic Cooperation and Development, No. 28(4), pp. 63-80.

20. Mundell, R.A. (1963). Capital mobility and stabilization policy under fixed and flexible exchange rates. Canadian Journal of Economic and Political Science, No. 29(4), pp. 475-485. Retrieved from: https://doi.org/10.2307/139336 
21. Ratha, A. (2012). Twin Deficits or Distant Cousins? Evidence from India. South Asia Economic Journal, No. 13(1), pp. 51-68. Retrieved from: https://doi.org/10.1177/139156141101300103

22. Salvatore, D. (2006). Twin deficits in the G-7 countries and global structural imbalances. Journal of Policy Modeling, No. 28(6), pp. 701-712. Retrieved from: https://doi.org/10.1016/j. jpolmod.2006.06.003

23. Sen, H., Kaya, A. (2016). Are the twin or triple deficits hypotheses applicable to post-communist countries? Bank of Finland, BOFIT Discussion Papers, No. 3.

24. Summers, L. (1986). Debt problems and macroeconomic policies. Harvard Institute of Economic Research Discussion Paper No. 1272. Cambridge: Harvard University.

25. Trachanas, E., Katrakilidis, C. (2013). The dynamic linkages of fiscal and current account deficits: New evidence from five highly indebted European countries accounting for regime shifts and asymmetries. Economic Modelling, No. 31, pp. 502-510. Retrieved from: https:// doi.org/10.1016/j.econmod.2012.12.026

26. Vamvoukas, G.A. (1999). The twin deficits phenomenon: evidence from Greece. Applied Economics, No. 31(9), pp. 1093-1100. Retrieved from: https://doi.org/10.1080/000368499323571 


\section{Appendix}

Table 1. VECM estimation on the current account balance in Hungary

\begin{tabular}{|l|c|c|c|c|}
\cline { 2 - 4 } \multicolumn{1}{c|}{} & \multicolumn{3}{c|}{$\Delta(\mathrm{CA} / \mathrm{GDP})_{\mathrm{t}}$} \\
\cline { 2 - 5 } \multicolumn{1}{c|}{} & Coefficient & Std. error & t-ratio & p-value \\
\hline \multirow{2}{*}{ const. $_{\Delta(\mathrm{BD} / \mathrm{GDP})_{\mathrm{t}-1}}$} & 0.621550 & 0.634029 & 0.9803 & 0.3304 \\
\hline$\Delta(\mathrm{BD} / \mathrm{GDP})_{\mathrm{t}-2}$ & -0.0685177 & 0.139706 & -0.4904 & 0.6254 \\
\hline$\Delta(\mathrm{CA} / \mathrm{GDP})_{\mathrm{t}-1}$ & 0.0129853 & 0.110963 & 0.1170 & 0.9072 \\
\hline$\Delta(\mathrm{CA} / \mathrm{GDP})_{\mathrm{t}-2}$ & -0.431772 & 0.120415 & -3.586 & $0.0006^{\star \star *}$ \\
\hline Crisis & -0.185821 & 0.118698 & -1.565 & 0.1221 \\
\hline Error-correction term & 0.832709 & 0.735343 & 1.132 & 0.2614 \\
\hline Mean dependent var & 0.157936 & 0.151062 & 1.046 & 0.2995 \\
\hline Sum squared resid & 0.106667 & S.D. dependent var & 2.575683 \\
\hline R-squared & 388.3246 & S.E. of regression & 2.389698 \\
\hline rho & 0.208997 & Adjusted R-squared & 0.139202 \\
\hline
\end{tabular}

Source: own estimation.

Table 2. VECM estimation on the budget deficit in the Czech Republic

\begin{tabular}{|l|c|c|c|c|}
\cline { 2 - 4 } \multicolumn{1}{c|}{} & \multicolumn{3}{c|}{$\Delta(\mathrm{CA} / \mathrm{GDP})_{\mathrm{t}}$} \\
\cline { 2 - 5 } \multicolumn{1}{c|}{} & Coefficient & Std. error & t-ratio & p-value \\
\hline const. & 0.259048 & 0.260663 & 0.9938 & 0.3238 \\
\hline$\Delta(\mathrm{BD} / \mathrm{GDP})_{\mathrm{t}-1}$ & -0.443370 & 0.137963 & -3.214 & $0.0020^{* * *}$ \\
\hline$\Delta(\mathrm{BD} / \mathrm{GDP})_{\mathrm{t}-2}$ & -0.172103 & 0.120620 & -1.427 & 0.1582 \\
\hline$\Delta(\mathrm{CA} / \mathrm{GDP})_{\mathrm{t}-1}$ & -0.0739674 & 0.0932667 & -0.7931 & 0.4305 \\
\hline$\Delta(\mathrm{CA} / \mathrm{GDP})_{\mathrm{t}-2}$ & -0.0446924 & 0.0666759 & -0.6703 & 0.5049 \\
\hline Crisis & -0.923411 & 0.642368 & -1.438 & 0.1552 \\
\hline Error-correction term & -0.118382 & 0.0980736 & -1.207 & 0.2316 \\
\hline Mean dependent var & 0.070667 & S.D. dependent var & 2.249611 \\
\hline Sum squared resid & 280.5017 & S.E. of regression & 2.031016 \\
\hline R-squared & 0.250988 & Adjusted R-squared & 0.184898 \\
\hline rho & -0.059158 & \multicolumn{2}{c|}{ Durbin-Watson } & 2.063885 \\
\hline
\end{tabular}

Source: own estimation. 
Table 3. VAR estimation on the budget deficit in Poland

\begin{tabular}{|c|c|c|c|c|}
\hline & \multicolumn{4}{|c|}{$\Delta(\mathrm{BD} / \mathrm{GDP})_{\mathrm{t}}$} \\
\hline & Coefficient & Std. error & t-ratio & $p$-value \\
\hline const. & -0.0657213 & 0.265068 & -0.2479 & 0.8052 \\
\hline$\Delta(\mathrm{BD} / \mathrm{GDP})_{\mathrm{t}-1}$ & 0.728444 & 0.114870 & 6.341 & $<0.0001^{* \star *}$ \\
\hline$\Delta(\mathrm{BD} / \mathrm{GDP})_{\mathrm{t}-2}$ & 0.187730 & 0.129649 & 1.448 & 0.1539 \\
\hline$\Delta(\mathrm{CA} / \mathrm{GDP})_{\mathrm{t}-1}$ & 0.0356469 & 0.0514622 & 0.6927 & 0.4917 \\
\hline$\Delta(\mathrm{CA} / \mathrm{GDP})_{\mathrm{t}-2}$ & -0.0564633 & 0.0843073 & -0.6697 & 0.5061 \\
\hline Crisis & -0.940005 & 0.458627 & -2.050 & $0.0457^{* *}$ \\
\hline Mean dependent var & -3.725000 & \multicolumn{2}{|c|}{ S.D. dependent var } & 1.851216 \\
\hline Sum squared resid & 41.24820 & \multicolumn{2}{|c|}{ S.E. of regression } & 0.908275 \\
\hline R-squared & 0.781159 & \multicolumn{2}{|c|}{ Adjusted R-squared } & 0.759275 \\
\hline$F(5,50)$ & 54.88424 & \multicolumn{2}{|c|}{ P-value (F) } & $3.95 e-19$ \\
\hline rho & -0.071826 & \multicolumn{2}{|c|}{ Durbin-Watson } & 2.141824 \\
\hline
\end{tabular}

Source: own estimation.

Table 4. VAR estimation on the current account balance in Poland

\begin{tabular}{|l|c|c|c|c|}
\cline { 2 - 4 } \multicolumn{1}{c|}{} & \multicolumn{3}{c|}{$\Delta(\mathrm{CA} / \mathrm{GDP})_{\mathrm{t}}$} \\
\cline { 2 - 5 } \multicolumn{1}{c|}{} & Coefficient & Std. error & t-ratio & p-value \\
\hline const. & -0.290275 & 0.593233 & -0.4893 & 0.6268 \\
\hline$\Delta(\mathrm{BD} / \mathrm{GDP})_{\mathrm{t}-1}$ & 0.142156 & 0.170644 & 0.8331 & 0.4088 \\
\hline$\Delta(\mathrm{BD} / \mathrm{GDP})_{\mathrm{t}-2}$ & -0.0849477 & 0.190236 & -0.4465 & 0.6571 \\
\hline$\Delta(\mathrm{CA} / \mathrm{GDP})_{\mathrm{t}-1}$ & 0.641103 & 0.140637 & 4.559 & $<0.0001^{* * *}$ \\
\hline$\Delta(\mathrm{CA} / \mathrm{GDP})_{\mathrm{t}-2}$ & 0.149848 & 0.133443 & 1.123 & 0.2668 \\
\hline Crisis & -0.0879021 & 0.570163 & -0.1542 & 0.8781 \\
\hline Mean dependent var & -3.119643 & S.D. dependent var & 2.452562 \\
\hline Sum squared resid & 122.6837 & S.E. of regression & 1.566421 \\
\hline R-squared & 0.629162 & Adjusted R-squared & 0.592078 \\
\hline$F(5,50)$ & 15.20218 & \multicolumn{2}{c|}{ P-value (F) } & $4.53 \mathrm{e}-09$ \\
\hline rho & 0.011067 & \multicolumn{2}{c|}{ Durbin-Watson } & 1.961698 \\
\hline
\end{tabular}

Source: own estimation. 